\title{
THE 16TH TO THE 18TH CENTURY PRINTED TURCICA PRESERVED IN POLISH COLLECTIONS
}

$\mathrm{I}$

believe there is no need to convince anyone how important it is to identify and record the cultural heritage of past centuries. In Poland, there are several independent projects on recording foreign Polonica (library and archival collections of Polish provenance, currently outside of Poland). Unfortunately, these projects are run without cooperation between research teams and institutions, and joint coordination has not been considered. I devoted a separate paper to this matter and it is ready to be published.

Equally important is the recording of foreign heritage located in our country - in Polish libraries, archives, museums and other collections. Unfortunately, this issue has not yet been met with broad sympathy, and thus far remains largely unrecognized.

It seems that more extensive studies of this type are not currently being conducted, although they should be of great importance; for example, issues related to old Polish notions of the world, geographical horizons, contacts with other countries (including the history of diplomacy), social communication and so on. The only example I can mention is my own research on old Polish collections of Turcica (which means the anti-Turkish writings), that has enabled me, among the other matters, to cover the issue of Polish-Ottoman relations from a bibliological and communicological perspective. This is the other side of the same coin, and a topic worthy of separate monographic study. The same concerns exist with regards to the state of gathering special collections in our libraries as well. In this paper, I would like to present the results of my ongoing examination concerning the recording printed Turcica 
(works thematically related to the Ottoman Empire) of the 16th to the 18th century, which have been preserved to date in Polish libraries to date.

It is worth explaining what I mean by Turcica. For me, these are texts coming from the epoch which tell us something about the former Ottoman Turkey or the way it was perceived from the European perspective, what stereotypes were connected with the term 'Turk', how the terms 'Mohammedan' or 'The Qur'an' were used as negatively-charged, emotional figures of speech. But it also includes texts indicating an interest in Turkey, such as dictionaries, grammars and so on.

The primary source of my studies is the central catalogue of old printed books of the National Library in Warsaw. This consists of several separate alphabetical subdivisions, out of which the most extensive are: the 16th to the 18th century foreign prints (published outside of Poland and thematically unrelated to it) and the 16th and 17th to 18th century Polonica.

Central catalogues are those catalogues recording collections of two or more libraries. According to the intentions of its originators, 'the Central Catalogue of Old Printed Books' was to have included descriptions of all documents printed between the 15th and 18th century, which are now in Polish collections.

Currently, 'the Central Catalogue of Old Printed Books of the National Library' has nearly a million index cards gathering information about the collections of almost hundred-and-forty Polish libraries. It is worth noting that this catalogue is a unique undertaking on a world scale.

Works on the catalogue of 16th to 18th century Turcica in Polish collections will be carried out in several stages: queries in the above mentioned alphabetical subdivisions of the central catalogue, queries in card catalogues of the National Library's collections and then checking the results will be checked based on the printed, card and electronic catalogues of other libraries.

Furthermore, the bibliological examination of at least some part of the preserved copies has to be completed. The planned book publication with my research results is to be not only a catalogue, but will also have to contain a descriptive section. I would like to present in this with a similar (though due to necessity much shorter) analyses, which have already been included in the book on Turcica, dated 1453 to 1572 . That research concerned the content of texts and changes occurring in this area during the period examined, creators' and recipients' circles of this type of literature; the role it played in the process of social communication; studies on readership traces in indi- 
vidual copies (degree of wear and tear, highlights, remarks at the margins, notes, creating bookbinding blocks by owners of books) and so on.

Currently, I am in the course of the first phase of work, collecting material from the central catalogue of 16th and 18th century foreign printed books. I am recording the 17th and 18th century Turcica ab ovo, and I have completed the information about the 16th century Turcica, most of which (until 1570) I have already registered in my habilitation dissertation. The results are promising. Up to now, I have found over two-hundred-and-fifty of the 16th century Turcica printed outside of Poland and over fifty domestic Turcica. These numbers will certainly increase after the completion of the work. When it comes to 17th century foreign Turcica, I have found so far ca. 250 so far and slightly fewer coming from the 18th century. By these figures I mean the titles, not copies, where there are many more of them. Many works have been preserved in several copies, more popular ones in a dozen or even more than twenty copies. However, it should be emphasized, there is still much more to be done, and those numbers will significantly increase, perhaps they even will double, as I am now approximately ihalfway through the catalogue of foreign printed books. Even so, at present, I cannot estimate the amount of Turcica published in Poland in the 17th and 18th centuries.

All this indicates that we are dealing with an important and interesting issue. The interest in Ottoman Turkey fits into the broader issues of geographical horizons during the Old Polish period - interest in other countries, cultures, geographical areas, and travelling (I intend to examine this issue in a separate project). Interest in Turkey has played a significant role - publications related to this matter were eagerly bought, read and collected.

I have included only the works that were published in my research, but it must be borne in mind that many manuscripts concerning the Orient, the Arab world, the Ottoman Empire also come from the same period. I have omitted prints on Arabia published in the 18th century. Although Mecca, Khwarezm, Arabia, Persia, Egypt were under the rule of the Ottoman Empire, in whole or in part for both long and short periods, I have not included works related to these regions in my enquiry. provide Descriptions of voyages to the Holy Land, which remained under the Ottoman rule, provide somewhat similar problems. Without an analysis, there is no way to determine, whether texts may be categorized as Turcica or not. Many of these types of concerns have been raised during my research. I can mention only a few of them as examples here.

In contrast to the previous eras, during the Age of the Enlightenment the world of Islam had no longer the face of 'the Great Turk' for Europeans. 
Words such as a 'Turk' and "a 'Muslim"” were no longer synonymous and did not describe the same reality. Turkey and Arabia had already become distinct from each other. Furthermore, the Prophet Muhammad was not considered to be a Turk, and therefore I have omitted his 18th century biographies, quite many of which have been preserved in our collections. These are works in Italian, German and French. As one can see, they attracted considerable interest. On the other hand, we still have many texts, especially editions of the Qur'an, that consider him as a 'Turk', call Islam a 'Turkish' religion, and the Qur'anitself, an Islamic Bible. In Polish libraries we have still a several dozen of copies of the Qur'an in Polish libraries in various editions - German, Latin and French - usually edited with commentaries.

News on Ottoman Turkey permeated society through different channels. The subject of my research is only the printed book. The above mentioned manuscripts are beyond the field of my current interests. The 18th century newspapers articles related to Turkey are also beyond the scope of my work. It is not possible to take into account works of a general nature, universal descriptions of the world, such as: cosmographies, encyclopaedias, geography handbooks, chronicles and historical works, or atlases. Nevertheless, I have made some exceptions, for example the works of Anton Friedrich Büsching (Grosse Erdbeschreibung, Vol. 5: Polen und Litauen... Das Reich Osmanische in Europe, Troppau 1785), as from our point of view it is unique in so far as it describes in a separate volume, among other things, Poland, Lithuania and Turkey. In addition, it was consistent to logically combine Poland and Turkey for Western writers and this fact should also be noted Polish scholars.

Furthermore, I believe that the image of Turkey (or of other countries) in school handbooks is in itself an interesting topic, worthy of separate study. How schools taught about Turkey (and also about Germany, England, France, Russia and so on) is an important issue to examine, as is how its image appears in atlases and encyclopaedias, which describe the entire world. In theory, these works should be objective. How it was in fact, remains an open question for now. This issue has its importance and it would be worthwhile to consider it separately, without including these considerations in the total mass of Turcica.

It would not be possible to track and count all those more or less extensive articles or references, without mentioning their analysis, in just one study. One of the proofs that this work is not easy to accomplish, is the book by Dariusz Dolanski: Trzy Cesarstwa: wiedza i wyobrażenia o Niemczech, Turcji $i$ Rosji w Polsce XVIII wieku [Three Empires: knowledge and perceptions of Ger- 
many, Turkey and Russia in the 18th century in Poland] (Zielona Góra 2013). In my opinion, the author has fulfilled the task he set himself in a not very convincing manner. He just failed.

One of the fundamental values of the catalogue recording Turcica swich was published over three centuries, is the possibility of tracing certain processes, such as how the attitude of Europe towards Turkey was changing. At the current stage of the research, it is difficult to formulate explicitly a statement about the changes that had occurred in presenting 'the Turk' in Western culture, but certain trends are clear and obvious. The 16th, and a significant part of the 17th, century was still a period of military confrontation. At that time, the greater part, if not the majority, of printed Turcica, relates to wars with Turkey, battles fought and sieges or predictions of the final victory over the-arch enemy. During subsequent centuries (especially in the 18th) Ottoman Turkey played a progressively smaller role as a superpower in the European arena, it westernized more and aroused progressively less fear among Europeans. As a consequence, the publications relating to it referred to then current international policy events to a significantly lesser extent. The printing press was no longer that sensitive barometer of current events, as it had been in the 16th century. The bulk of publishing production moved further towards satisfying curiosity (including scientific inquiry) and entertainment. Gradually, the descriptions of voyages become more frequent than those describing battles. My work provides a bibliological and communicological foundation for the studies in Turkology.

Some of these works have become publishing bestsellers, have been repeatedly reprinted (sometimes even in subsequent centuries), translated into different languages and to this day many of their copies have been preserved in Polish collections to this day (a dozen, or more than twenty). And contrary to popular contemporary belief, these were not only calls for a war against Turkey, but to a large extent texts carrying certain knowledge about this country, its customs, people, geography, cities and so on. However, the first mentioned subject also featured.

As I have written in relation to the 15th century, "equally popular, as in the whole of Western Europe, was the description of Bernhard von Breidenbach's voyage (as many as 17 copies have been preserved up to the present day). The fear of the Turkish threat is reflected in a significant number (14) of copies of John Annius' De Futuris Christianorum triumphis in Saracenos. And this combination perfectly reveals the mix of European feelings in relation to the Orient - fear and fascination. 'The threat was feared', but at the 
same time curiosity, was as strong as fear. Emphasis has been distributed more or less evenly herein. Letters of indulgence concerning participation in the crusade were found in 18 copies, whereas seven letters of Pius II, and nine of Mehmed II have been found, as well as twenty copies of the, works of Sagundin and George of Hungary. As a reflection of apocalyptic fears, among which Turks were one of the elements, we can find fifteen copies of the divine revelations of St. Methodius. Evidently, we must also consider to what extent the current state of preservation may be considered as being representative. However, it seems obvious that this is a reflection of real phenomena and basing on it one can draw cautious conclusions may be based on this. These proportions are certainly not entirely coincidental." ${ }^{1)}$

Similar conclusions can be drawn for the 16th century: "An expression of sincere interest in facts about Turkish history, religion, customs, political system and so on are also the books that were brought from abroad, gathered and read, and copies of which have been preserved in Poland up to now such as: Johannes Adelphus, Die Tuerckisch Chronica von irem Ursprung, Anefang und Regiment, biss uff dise Zeyt, sampt irem Kriegen und Streyten mit den Christen begangen, erbaermerklich zu lessen, Strasbourg 1516; Anfang, ursprung und herkommen der Tuercken auff das aller kurtzest begriffen. Von der Tuercken glauben, und ihrer Religion... Worms 1535; Joannes Aventinus, Türckische Historien. Von der Türcken Ankunft, Regierung, Königen u. Keysern, Kriegen, Schlachten, Victorien u. Siegen wider Christen, Frankfurt 1563 and 1570; Marinus Barletius, De vita, moribus ac rebus, praecipue adversus Turcas, gestis Georgii Castrioti Scanderbegi Epirotarum principis, Strasbourg 1537 (also in Polish translation); Andrea Cambini, Libro della origine de Turchi et imperio delli Ottomani, Florence 1529; Florence 1537; Laonicos Chalcocondyles, De origine et rebus gestis Turcorum libri decem, Bazel 1556 and 1562; Wolfgang Drechsler, De Sarracenorum et Turcorum origine et rebus gestis chronicon auctum, et ad annum 1567 usque perductum, Bazel 1567 and Frankfurt 1568 (...). The list is long. No need to even mention such book store best sellers as Omnium gentium mores by John Boemus or Peregrinatio in Terram Sanctam by Bernhard von Breidenbach. It is these books that were the most extensively read, and it was these that people were more vividly fascinated with, rather than with any anti-Turkish polemics.

All these works have been preserved in a considerable number of copies, not counting the number of calls for 'a crusade'. It should be noted that,

1) Imago Turci (2013: 256). 
although in thelatter case we know of more titles, they have survived in single copies only. In contrast, even though there are fewer titles of texts in a broader context (anthropological, historical), each one of them has survived in a number of copies (sometimes a dozen or so, or more than twenty). This is a very important indication that points to what type of literature was the most desirable, sought after and most read, what Old Polish readers were paying particular attention to and what was less significant to them"2).

In 17th and 18th centuries this trend was continued. In the Baroque era, anti-Turkish speeches were published (Bosquier Philippus, Orator Terrae Sanctae et Hunagiae seu Sacrarum Philippicarum in Turcarum Barbariem, et importunas Christianorum discordias, notae, Douai 1606; Cologne 1611; 15 copies) as well as less popular historical works (Besold Christoph, Historia Constantinopolitana post avulsum a Carolo Magno Occidentem, ad nostra usque tempora deducta, Argentorati 1634; 11 copies, or Gilles Pierre [Gyllius Petrus], De Constantinopoleos topographia lib. IV, Leyden 1632; in a record amount of 34 copies).

Turkey entered European popular culture for good in the 18th century, following the emerging fashion for exoticism and Orientalism. Not only erudite theses on the Ottoman state, descriptions of voyages to the Bosphorus, or grammars and handbooks to learn the Turkish language were published, but also comedies, operas, operettas, or even ballet, based on the Turkish motifs. During the whole period examined, there was not too much interest in Islam as a religion, or commentaries on it, or comparisons between Islam and the Christian religion. Nevertheless, as I have mentioned above, we can observe a great interest, or even fascination, for the Qur'an itself. A lot of curiosity was directed towards the biography of the Prophet Muhammad. Invariably there was also an interest in Turkish customs, attire and designs of applied art. At that time, descriptions of voyages, ethnographic books (de Chevigny, La science des personnes de la cour de l'epee et de la robe, many editions; 33 copies), histories and general works (A.F. Büsching, mentioned above, in total fifty-eight copies of two editions) had become publishing best sellers.

We identify ourselves through 'the other' and with regard to 'the other'. 'The stranger' allows us to determine our own identity. In modern history, 'the stranger' was very often identified as a Turk or Muslim. Therefore, any reflection on the presence of literary and scientific works related to Turkey, or those in which Turkish motifs are mentioned, is at the same time, also

2) Tafiłowski (2013: 110-117). 
a reflection on ourselves, the world view of our ancestors, the inhabitants of the Latin Europe, members of the Western Christian community.

\section{BIBLIOGRAPHY}

Imago Turci: studium $z$ dziejów komunikacji społecznej w dawnej Polsce (1453-1572), Lublin 2013.

Tafiłowski (2013) = Piotr Tafiłowski, „Imago Turci”: studium z dziejów komunikacji spolecznej w dawnej Polsce (1453-1572), Wydawnictwo UMCS, Lublin 2013. 